\title{
Gonzalo García de Santa María, de Zaragoza, casa con Violante de Bellviure, de Valencia. Estrategias matrimoniales conversas
}

\author{
José Hinojosa Montalvo* \\ Universidad de Alicante
}

ORCID ID: https://orcid.org/0000-0003-2323-649X

En 1391 y 1413 buena parte de los judíos de los reinos de Valencia y Aragón se convirtieron por la fuerza al cristianismo, y entre ellos los Bellviure y los Santa María, que con el paso del tiempo se integraron entre los ciudadanos honrados de Valencia y Zaragoza, respectivamente, llegando a gozar de una destacada posición social y económica. La boda de Violante de Bellviure, de Valencia, con Gonzalo García de Santa María, de Zaragoza, nos permite descubrir a través de la carta dotal de la primera y la donación de bienes del segundo diversos aspectos de las relaciones entre los conversos de Valencia y Zaragoza, el nivel de riqueza y las estrategias matrimoniales de ambas familias.

Palabras Clave: conversos; Aragón; Valencia; matrimonio; siglo XV.

Gonzalo García of Santa María, from Zaragoza, Marries Violante of Bellviure, from Valencia. Converse Marriage Strategies.- In 1391 and 1413 most of the Jews in the Kingdom of Valencia and Aragon where converted by force to Christianity, amongst them the Bellviure and the Santa María, who with the passing of time merged with the honorable citizens of Valencia and Zaragoza, respectively, achieving a prominent social and economic status. The wedding of Violante de Bellviure, of Valencia, with Gonzalo García de Santa María, of Zaragoza, allowed us to discover by the endowment letter of the first and the donation goods of the second, different aspects of the relationships between the converts of Valencia and Zaragoza, the level of wealth and wedding strategies of both families.

KeYwords: Converts; Aragon; Valencia; Marriage; 15th-Century.

*johimon@yahoo.es

Copyright: (C) 2020 CSIC. Este es un artículo de acceso abierto distribuido bajo los términos de la licencia de uso y distribución Creative Commons Reconocimiento 4.0 Internacional (CC BY 4.0). 


\section{INTRODUCCIÓN}

Si en la ciudad y reino de Valencia la conversión masiva de los judíos al cristianismo se debió a la violencia de los cristianos en el asalto a las principales juderías del reino en julio de 1391, en el reino de Aragón -salvo pequeñas alteraciones en localidades como Aínsa, Barbastro, Jaca, Huesca, Monzón, Tamarite, Albarracín y Teruel- la población hebrea pudo librarse de estas persecuciones, en buena medida por la presencia del monarca en Zaragoza. Pero unos años después, en las primeras décadas del siglo Xv, tampoco en Aragón los judíos lograron escapar de los bautismos forzosos, como han puesto de relieve los estudiosos del tema, fruto de dos sucesos significativos y bien estudiados, como fueron las predicaciones de fray Vicente Ferrer y la Disputa de Tortosa (14121414) $)^{1}$.

Ya en el siglo XVI, el cronista Jerónimo Zurita captó perfectamente el sentido de ambos eventos, y así lo consignó en sus Anales:

En el estío del año pasado [1413] se convirtieron de las sinagogas de Zaragoza, Calatayud y Alcañiz más de doscientos; y entre ellos se convirtió un judío de Zaragoza llamado Todroz Benbenist, que era muy noble en su ley, con otros siete de su familia, y después sucesivamente en los meses de febrero, marzo, abril, mayo y junio deste año, estando el papa con su corte en aquella ciudad de Tortosa, muchos de los más enseñados judíos de las ciudades de Calatayud, Daroca, Fraga y Barbas-

1 Vid. Asunción Blasco Martínez, «El impacto de los ataques de 1391 y el adoctrinamiento de Tortosa en la sociedad judía aragonesa», en La Península Ibérica en la era de los descubrimientos, 1301-1492 Actas III Jornadas Hispano-Portuguesas de Historia Medieval, coords. Isabel Montes Romero-Camacho, Antonio Claret García Martínez y Manuel González JimÉnez (Sevilla: Consejería de Cultura de la Junta de Andalucía, 1997) vol. I, págs. 259-288 y «La conversión de judíos y su repercusión en la sociedad aragonesa durante los primeros años del reinado de Alfonso el Magnánimo», en XVI Congresso Internazional d Storia della Corona d'Aragona. La Corona d'Aragona ai tempi di Alfonso il Magnanimo (Napoli, 1997). Atti, 1 (Napoli: Paparo Edizioni, 2000) págs. 841-859: 845-846; Philip DaILEAder, San Vicente Ferrer. Su mundo y su vida (Valencia: Universitat de València, 2019), y Miguel Ángel Motis Dolader, «La conversión de judíos aragoneses a raíz del edicto de expulsión», en Encuentros en Sefarad. Actas del Congreso. Los judios en la Historia de España, coords. Francisco RuIz Gómez y Manuel Espadas Burgos (Ciudad Real: Instituto de Estudios Manchegos, 1987) págs. 217-252. 
tro se convirtieron y se bautizaron hasta en número de ciento y veinte familias, que eran en gran muchedumbre; y todas las aljamas de Alcañiz, Caspe y Maella se convirtieron a la fe en general, que fueron más de quinientas personas; y tras éstos se convirtieron la aljama de Lérida y los judíos de la villa de Tamarit y Alcolea; y fueron en número de tres mil los que entonces se convirtieron en la corte del Papa y fuera della, según parescié, con puro corazón ${ }^{2}$.

Fruto de este bautismo masivo de judíos fue la desaparición de algunas comunidades del reino, quedando otras muy debilitadas el resto de la centuria ${ }^{3}$. En Aragón entre los convertidos figuraban destacados personajes, que pronto, como veremos, se integraron en las élites de los ciudadanos honrados.

El tema de los conversos en Aragón y Valencia ha generado una abundante bibliografía en los últimos años, aunque son escasas las monografías y muchos de los trabajos se centran en las décadas finales del siglo Xv, a partir del establecimiento del Santo Oficio en estos reinos, o en el momento inicial de la conversión, cuando su condición de neófitos está perfectamente identificada en la documentación ${ }^{4}$. A partir de los años treinta, integrados ya en la sociedad de los cristianos viejos, su pista se hace más difícil de seguir en los documentos hasta que, de nuevo, vuelven a ser identificados como grupo e individualizados por la Inquisición.

2 Jerónimo Zurita, Anales de la Corona de Aragón, edición de Ángel Canellas (Zaragoza: Institución Fernando el Católico, 1967-1977) Libro IX, cap. LVII.

3 Vid. Miguel Ángel Motis Dolader, Los judios de Aragón en la Edad Media (siglos XIII-XV) (Zaragoza: Caja de Ahorros de la Inmaculada, 1990) pág. 23.

4 Vid. José Cabezudo Astráin, «Los conversos aragoneses según los procesos de la Inquisición», Sefarad 18 (1958) págs. 272-282; Yoseph KaPlan, (ed.), Jews and conversos, Studies in society and the Inquisition (Jerusalem: World Union of Jewish Studies, 1985); Mark D. Meyerson, "Aragonese and Catalan Jewish Converts at the Time of the Expulsión», en The Frank Talmage Memorial Volume (Jewish History, n. VI), vol. II (Haifa: University Press, 1992) págs. 131-149; Yom Tov Assis y Yoseph Kaplan, (eds.), Jews and Conversos at the Time of the Expulsión (Jerusalem: The Zalman Shazar Center for Jewish History, 1999), y Norman Roтн, Conversos, Inquisition and the Expulsion of the Jews from Spain (Madison: University of Wisconsin Press, 2002). 
No vamos a entrar en analizar la evolución de los conversos en la Corona de Aragón, en concreto en los reinos de Aragón ${ }^{5}$ y de Valencia ${ }^{6}$,

5 En el reino de Aragón la bibliografía sobre conversos es extensa, figurando, entre otras, las obras siguientes: BLASCO MARTíNEZ, «La conversión de judíos y su repercusión en la sociedad aragonesa durante los primeros años del reinado de Alfonso el Magnánimo», págs. 845-846; Asunción Blasco MarTíNEZ, «Hagionomástica en judeoconversos aragoneses», Memoria Ecclesiae XXIV (2004) págs. 121-144 y «Judíos y conversos en el reino de Aragón», en Chrétiens et Juifs au Moyen Âge. Sources pour la recherche d'une relation permanente, eds. Flocel Sabaté y Claude Denjean (Lleida: Milenio, 2006) págs. 207-234; Encarnación Marín Padilla, Maestre Pedro de la Cabra. Médico converso aragonés del siglo XV, autor de unas coplas de arte menor (Zaragoza: E. Marín, 1998) y Panorama de la relación judeoconversa aragonesa en el siglo XV: con particular examen de Zaragoza (Madrid: E. Marín, 2004); Miguel Ángel Motis DolaDER, «Líneas programáticas de la legislación sobre judíos y conversos en el reino de Aragón en el siglo XV», en III Jornadas hispano-portuguesas de Historia Medieval, coords. Isabel Montes Romero-Camacho, Antonio Claret García Martínez y Manuel GonzÁlez Jiménez (Sevilla: Consejería de Cultura de la Junta de Andalucía, 1997) vol. 1, págs. 115-164, «Régimen alimentario de las comunidades judías y conversas en la Corona de Aragón en la Edad Media», en Actes Ir Col·loqui d'Història de l'alimentació a la Corona d'Aragó 8 (Lleida: Cuaderns de l'Institut, 1995) págs. 205-362 y «La conversión de judíos aragoneses a raíz del edicto de expulsión», y José Ángel SeSma MuÑoz, «Violencia institucionalizada: El establecimiento de la Inquisición por los Reyes Católicos en la Corona de Aragón», Aragón en la Edad Media VIII (1989) págs. 659-674 y «Los Santángel de Barbastro: estructura económica y familiar», Aragón en la Edad Media IX (1991) págs. 121-137.

${ }^{6}$ Para el reino de Valencia, entre otros, pueden consultarse: Patricia BANERES, «Prosopografía de los conversos valencianos en el tránsito de los siglos XV-XVI. La problemática de las fuentes inquisitoriales», en En el primer siglo de la Inquisición Española: fuentes documentales, procedimientos de análisis, experiencias de investigación, coord. José María Cruselles Gómez (Valencia: Universitat de València, 2013) págs. 273-294; Juan Antonio BARrio BARrio, «Los judeoconversos en la frontera sur del reino de Valencia (ss. XIV-Xv)», Anales de la Universidad de Alicante. Historia Medieval 15 (20062008) págs. 119-137 y «Los conversos de judío en la ciudad de Xàtiva. Creencias y prácticas religiosas a través de la visión del otro», Medievalismo 23 (2013) págs. 61-99; Jaime CASTILlo SAInZ, «De solidaritas jueves a confraries de conversos: entre la fossilització i la integració d'una minoria religiosa», Revista d'Història Medieval 4 (1993) págs. 183-206; José María Cruselles Gómez, (coord.), En el primer siglo de la Inquisición Española: fuentes documentales, procedimientos de análisis, experiencias de investigación (Valencia: Universitat de València, 2013); Enrique Cruselles Gómez, José María Cruselles Gómez y José Bordes García, Conversos de la ciudad de Valencia. El censo inquisitorial de 1506 (Valencia: Institució Alfons el Magnànim, 2015); Ricardo GARCÍA CÁRCEL, «Families converses valencianes», en Lluís de Santàngel Un nou home un mon nou (Valencia: Generalitat Valenciana, 1992) págs. 207-220; José HinojosA 
dado que no es ese el objetivo del presente estudio, sino el matrimonio entre los hijos de dos familias conversas de ambos reinos, varias generaciones después del bautismo y su inserción en la sociedad cristiana.

\section{Los SAnta María de Zaragoza}

Tras el bautismo los conversos de judío se fueron integrando pacíficamente en la sociedad cristiana, tras adoptar en algunos casos patronímicos de carácter hagiográfico, como Santángel, San Juan, San Vicente, Santa Cruz o Santa María. Estos patronímicos de santos fueron más frecuentes en el reino de Aragón que en el de Valencia, donde los conversos con estos apellidos son de origen foráneo, precisamente aragoneses, en concreto los Santángel.

Los conversos no formaban un colectivo social homogéneo, pero lo cierto es que aquellos que habían pertenecido a los estamentos más altos

Montalvo, «Los conversos de judío valencianos en el siglo xv: entre el desarraigo y la asimilación», en La Península Ibérica en la era de los descubrimientos, 1301-1492 Actas III Jornadas Hispano-Porgtuguesas de Historia Medieval, coords. Isabel MonTES Romero-CAmacho, Antonio Claret García Martínez y Manuel González Jiménez (Sevilla: Consejería de Cultura de la Junta de Andalucía, 1997) vol. I, págs. 69-98, «Conversos y judaizantes en Valencia a fines de la Edad Media», Anales Valentinos XXII (1996) vol. 44, págs. 251-274, «Lluís de Santàngel: un converso valenciano en la corte de los Reyes Católicos», en Entre la péninsule ibérique et l'Amérique: cinq-centième anniversaire de la mort de Christophe Colomb, ed. Rica AmRAN (Paris: Indigo-Université Jules Verne, 2007) págs. 113-174, «La hora de la muerte entre los conversos valencianos», Cuadernos de Historia de España LXXXIII (2009) págs. 81-105 y «Conversos valencianos y cultura material», Cuadernos de Historia de España LXXXV-LXXXVI (2011) págs. 365-386; José Luis Luz CoMPANY, «Familias judías-conversas. Aproximación a los neófitos valencianos del siglo XIV», Espacio, Tiempo y Forma, serie III-6 (1993) págs. 409-424; Rafael Narbona VizCaíno, «Los conversos de judío. Algunas reflexiones sobre una bibliografía de historia urbana medieval», en Crétiens et juifs au Moyen Âge. Sources pour la recherche d'une relation permanente, eds. Flocel SABATÉ y Claude Denjean (Lleida: Milenio, 2006) págs. 201-240 y «La incorporación de los conversos a la gestión hacendística de la ciudad de Valencia (1391-1427)», en En el primer siglo de la Inquisición Española: fuentes documentales, procedimientos de análisis, experiencias de investigación, coord. José María CRuselles Gómez (Valencia: Universitat de València, 2013) págs. 17-42, y Ferran GarcíA-Oliver, (coord.), Jueus, conversos $i$ cristians. Mons en contacte (=Revista d'Història Medieval 4 [Valencia: Facultat de Geografia i Història, 1993]). 
de la sociedad judía pronto consiguieron una posición preeminente en la sociedad de cristianos viejos, aspirando a cargos y honores, como los Santángel, los Caballería, los Ruiz, etc., linajes que disponían de gran solvencia económica, lo que les permitía integrarse en los grupos dirigentes de la sociedad de sus respectivas ciudades.

Estas notables familias conversas, integradas pronto en el grupo privilegiado de los ciudadanos honrados, tejieron una tupida red de alianzas sociales, económicas y políticas con otras familias de Zaragoza o incluso de fuera, como fue el caso de los Santa María con los Bellviure de Valencia.

La familia nuclear era el modelo imperante en la sociedad bajomedieval peninsular, incluyendo también a los parientes en un segundo plano, unidos por vínculos de consanguinidad. Pronto vemos a los Santa María vinculados a otras importantes familias conversas a través del matrimonio, como los Sánchez de Calatayud/Cavallería, y así, por ejemplo, el mercader Gonzalo García de Santa María casó con Brianda Sánchez de Calatayud, esta en segundas nupcias.

¿Qué sabemos de la familia Santa María de Zaragoza? De entrada digamos que no existe ninguna monografía sobre la misma, apareciendo las noticias más extensas en la monografía que F. Cantera Burgos dedicó hace más de sesenta años a Alvar García de Santa María y su familia de conversos burgaleses, aunque, a pesar del apellido los de Aragón no descendieran del mismo linaje. El ilustre historiador, siguiendo el testamento de Gonzalo García de Santa María, ciudadano de Zaragoza, del año 1519, publicado por Serrano y Sanz ${ }^{7}$ hizo a Gonzalo descendiente de los Levís, judíos de Soria. Uno de ellos se convirtió y tomó el nombre de Tomás, y fue hermano del obispo don Pablo y padre del mercader Gonzalo García de Santa María. Este casó en segundas nupcias con Brianda Sánchez, teniendo por hijo a micer Gonzalo de Santa María, jurista, y la madre de mosén Ramón Cerdán ${ }^{8}$.

7 Vid. Manuel Serrano y SanZ, «El testamento de Gonzalo García de Santa María», Boletín de la Real Academia Española T. I (1914) págs. 470-478.

8 Vid. Francisco Cantera Burgos, Alvar García de Santa María y su familia de conversos. Historia de la judería de Burgos y de sus conversos más egregios (Madrid: Instituto Arias Montano, 1952) pág. 379. 
A pesar de que publicaciones como la Gran Enciclopedia Aragonesa sigue considerando el linaje como «integrante de la rama aragonesa de una conocida familia de conversos radicada en Burgos», hoy estos orígenes no se mantienen y la opinión de los expertos es que entre los convertidos a raíz de la disputa de Tortosa figuraba el médico Tadroz Bienvenist, que era físico del arzobispo de Zaragoza García Fernández de Heredia. Tomó de cristiano el nombre de Tomás García de Santa María, médico y ciudadano de Zaragoza, siendo su esposa Beatriz de la Cavallería, que en 1454 es citada ya como viuda. Fueron hijos suyos el mercader Gonzalo García de Santa María, y Violante García de Santa María $^{9}$. A la postre, tenía razón Jerónimo Zurita, siempre con tan buen ojo crítico.

Centrándonos en Gonzalo García de Santa María, padre de nuestro protagonista, ya hemos visto que él mismo estrechó lazos con el linaje de los Sánchez de Calatayud/Cavallería, mientras que su hija Beatriz García de Santa María, casó con el caballero Galacián Cerdán, hijo del caballero Ramón Cerdán y sobrino del ciudadano Pedro Cerdán. Las capitulaciones se firmaron en octubre de 1460 y la esposa aportó como dote 55.000 sueldos, de los cuales 12.000 se entregaron al contado y el resto, el $78,1 \%$ de la cuantía en censales; una renta de 1.000 sueldos sobre la villa de la Puebla de Híjar, otros 1.000 sobre Lezera y Almonacid de la Cuba, 400 sueldos más sobre la aljama de Belchite, 350 sobre la Pobla de Albortón y 425 sobre Sádaba ${ }^{10}$. Tuvo también un hijo llamado Pedro García de Santa María, que testó el 18 de marzo de 1477 ante el notario Antonio Manrán, de Zaragoza, dejando como heredero universal a su padre. Por un documento del 27 de abril de 1478 sabemos que Pedro tenía relaciones con Ramón Siscar, comendador de Torrent (Valencia), al que debía en el momento de su muerte 100 florines, pues

9 Vid. Marín Padilla, Panorama de la relación judeoconversa aragonesa en el siglo $\mathrm{XV}$.

10 Vid. Susana Lozano Gracia, Las élites en la ciudad de Zaragoza a mediados del siglo XV: La aplicación del método prosopográfico en el estudio de la sociedad (Zaragoza: Universidad, 2007) págs. 910-911. La autora resalta la diferencia en la composición del patrimonio de las dos familias, pues el noble Cerdán aporta el lugar de Uysón y tierras colindantes, el castillo de Pardina de Guarda, una residencia en la ciudad y la posibilidad de firmar un censal por valor de 20.000 sueldos. 
ese día Gonzalo García de Santa María, mercader, nombró procurador a Pere de Maya, escudero de Zaragoza, para recuperar dicha deuda ${ }^{11}$.

En cuanto a Gonzalo García de Santa María, el jurista y el miembro familiar de más renombre, vió la luz el 31 de mayo de 1447, y fue ciudadano de Zaragoza, aunque no nació allí, siendo trasladado de niño a la capital del reino de Aragón. Sus biógrafos citan su matrimonio con la conversa valenciana Violante Bellviure (Velvivre, según Serrano y Sanz), del que nos vamos a ocupar. De él nació Hipólito Santa María, y Brianda Santa María, casada de Pedro de Reus, con la que se llevó mal, a pesar de que, como dice Gonzalo de Santa María en su testamento, «yo di buen casamiento y dote según mi patrimonio, lo qual ella poco me ha agradecido», por lo que en el testamento tan solo le dejó cinco sueldos por legítima, declarando heredero universal a su hijo Gonzalo.

Sus actividades intelectuales están bien documentadas desde 1469, figurando en el consejo de Juan de Lanuza, Justicia de Aragón, y en 1497 era lugarteniente del Justicia. En 1501 era jurado de Zaragoza y quizá fuera consejero del arzobispo Alfonso, gobernador general de Aragón. Fernando el Católico le encargó la biografía de su padre, Juan II.

Testó el 10 de mayo de 1519 y falleció en 1521, siendo enterrado en el monasterio de San Francisco de Zaragoza, donde también yacía su padre. A sus biógrafos lo que más les ha interesado ha sido su faceta de humanista y jurista al servicio de la ciudad de Zaragoza y de los monarcas Juan II y Fernando el Católico. Su testamento nos permite conocer la impresionante biblioteca que poseía, la mejor de la Península en aquellos momentos, reflejo del amor que sentía hacia los libros. En su epitafio se le denomina «elocuentísimo jurisconsulto» y Serrano y Sanz lo calificó de «peritísimo en Derecho, en Letras latinas y en Historia» ${ }^{12}$.

Gonzalo García de Santa María, además de historiador y cronista, compaginó su labor jurídica con el cultivo de las letras latinas y nume-

11 Archivo de Protocolos del Real Colegio de Corpus Christi. Valencia (APRCCC), Protocolos de Guillem Exernit, núm. 23.002.

12 Vid. Serrano y Sanz, «El testamento de Gonzalo García de Santa María», pág. 470. 
rosas traducciones de autores clásicos, como por ejemplo Platón, alimentando así el funcionamiento de la imprenta de su amigo Pablo Hurus ${ }^{13}$.

\section{LA FAMilia BellviUre}

Lo primero que hay que hacer es una precisión onomástica con respecto a la familia Bellviure/Benviure, y es que a partir de los años posteriores a su conversión al cristianismo aparece con las dos grafías indistintamente. Podría pensarse que se tratara de dos familias distintas,

13 Reproduzco a continuación la obra intelectual de Gonzalo García de Santa María, que aparece en la voz sobre dicho personaje en la Gran Enciclopedia Aragonesa: «Es autor de traducciones de obras latinas de carácter moral y litúrgico, como los Evangelios y epistolas (Zaragoza 1485); las Vidas de los santos religiosos (¿Zaragoza 1491?) de San Jerónimo; un Cordial de las cuatro cosas postrimeras (Zaragoza 1491), de Dionisio el Cartujano; el Tratado de las diez cuerdas de la vanidad del mundo (¿Zaragoza 1494?) atribuido a San Agustín. Nicolás Antonio le atribuye cierta Supleción de los modernos a la cosmografía antigua y crónica de la parte de Asia (Zaragoza ¿1488-1491?), de un franciscano llamado Grifón. Tradujo en coplas el Catón en latín e en romance (Zaragoza 1494). Editó y corrigió los Fori Aragonum (Zaragoza 1496) y las Constituciones Synodales Archiepiscopatus Cesaraugustani (Zaragoza 1500). Editó el Dialogus pro Ecclesia Dei contra Sinagogam (¿Zaragoza 1497?), de Teobaldo, trabajo con el que muestra su preocupación apologética y de catolicismo ortodoxo, aunque hubiera tenido roces con la Inquisición aragonesa. Aparte de algunas cartas, su obra de más peso fue su labor historiográfica en torno a la familia real de Aragón, toda ella en latín. El Árbol de la sucesión de los reyes de Aragón, que no conservamos, parece que fue escrito entre octubre de 1497 y 1499, en donde, además de genealogía, se discute el problema de la sucesión femenina. Tampoco se conserva completa una Crónica de Aragón -aunque sí fragmentos extractados por Ustarroz y Andrés-, la cual parece que abarcaba el mismo período que el Árbol, según el sumario de este hecho por Zurita. La obra histórica más importante conservada es la Serenissimi Principis Joannis Secundi Aragonum Regis vita, biografía humanística con abundantes reminiscencias de los clásicos, sobre todo de Salustio, en donde se expone una particular ideología histórico-política, basándose toda la obra sobre la antítesis que muestra la oposición política de la Generalitat catalana al espíritu de la monarquía; Gonzalo se sitúa en la concepción de la monarquía según la línea continuada por los conversos: reconocen en el monarca atributos del Antiguo Testamento y es responsable directo ante Dios y el Papa; subyace la idea de providencialismo e imperialismo unificador». Voz «Gonzalo García de Santa María», en Gran Enciclopedia Aragonesa (accesible en línea en <http://www.enciclopedia-aragonesa.com/ voz.asp?voz_id=6168\&tipo_busqueda=1\&nombre=Garc $\%$ EDa $\% 20 \mathrm{de} \% 20 \mathrm{Santa} \% 20$ Mar\%EDa\&categoria_id=\&subcategoria_id=\&conImagenes=>). 
pero no es así, dado que en ocasiones en un mismo documento el notario ha utilizado las dos grafías. En cualquier caso, Benviure es el apellido más utilizado en los documentos, aunque aquí emplearemos el de Bellviure, dado que fue el utilizado por el notario que elaboró la documentación matrimonial.

El apellido Bellviure aparece entre los conversos de Valencia a raíz del bautismo tras el asalto a la judería en julio de 1391. En ese año y en los inmediatos se han documentado seis personajes apellidados Bellviure/Benviure, dedicados a la actividad mercantil, la correduría y la artesanía de la seda. Recordemos que el apellido Benviure también existía entre los cristianos de la ciudad antes de 1391. Así, vemos como en septiembre del año 1388 Usua Sibilí tenía una apelación interpuesta a dos pleitos, uno con Francesc de Benviure, mercader de Valencia, y otro con Pere de Graus, ambos de Valencia ${ }^{14}$. Si tenemos en cuenta que su pariente Salomó Sibilí, mercader, al convertirse al cristianismo en julio de 1391 pasó a llamarse Guillem de Bellviure, ejerciendo como sedero y mercader, cabe pensar que los Benviure cristianos con los que mantenían vínculos en los negocios, fueran los que al apadrinarlo dieran nombre a este nuevo linaje de conversos. De su rápida integración en el mundo de los cristianos viejos da cuenta el hecho de que en 1397 aparece ya como ciudadano de Valencia.

No fueron los Sibilí - una de las familias judías más destacadas de la judería-, el único origen del linaje Bellviure, pues también tenemos documentado algún personaje de la familia Osca que tomó este apellido. Es el caso de Vidal d'Osca, un personaje también notable en la aljama valenciana, que el 13 de noviembre de 1382 recibió la carta de franquicia que le entregó la ciudad y el 16 de febrero de 1390 la reina Violante, a petición de algunos familiares, le concedió el oficio de juez del tribunal rabínico de la aljama, a beneplácito de ella.

El caso de Osca es representativo de lo que les debió suceder a algunos judíos de Valencia, que a causa del asalto a la judería en 1391 se convirtieron al cristianismo, en este caso adoptando el nombre de Pere de Benviure. En su nueva situación de converso de judío se mantuvo

${ }^{14}$ Archivo de la Corona de Aragón (ACA), C. reg. 1834, fol. 62r y reg. 1835, fol. 40r. 
hasta que decidió fugarse a tierra de moros, no sabemos si Granada o el norte de África, para recuperar su antigua religión. No le debió gustar su nueva residencia y con el perdón real regresó a Valencia, donde recuperó su antiguo oficio de «bedin» el 26 de abril de 1394, por concesión de la reina Violante, señora de la judería, que no deseaba perder las rentas que le proporcionaba la misma ${ }^{15}$.

El problema es establecer la genealogía exacta de los Bellviure desde su bautismo a los años setenta del siglo xv, ya que solo a partir de los años veinte de esta centuria la trama familiar puede seguirse con precisión. Los primeros Bellviure documentados son, por orden alfabético: Gabriel de Bellviure, corredor (1402); Gabriel de Bellviure, mercader (1403), calificado como senior en 1423; Gabriel de Bellviure, sedero y tejedor de velos de seda, vecino de Valencia desde 1399; Guillem de Bellviure, antes Salomó Sibilí, mercader y ciudadano de Valencia; Lluís de Bellviure, hijo de Pere de Bellviure, mercader y ciudadano de Valencia (1399-1402); Pere de Bellviure (1399), mercader y ciudadano de Valencia; Pere de Bellviure, sedero, muerto ya en 1412.

E. Cruselles, en su monografía sobre los mercaderes de Valencia en la Baja Edad Media, al plantearse el origen geográfico de los mismos, entre otros muchos ejemplos señaló el de la familia Bellviure, que fueron clientes del notario Vicent Saera, base de su estudio, citando el caso de Guerau Bellviure, hijo de Francesc, mercader de Valencia, cuñado de Francesc d'Artés, en tanto que un tal Gabriel Bellviure tenía dos hijos, también comerciantes, llamados Lluís y Gabriel. La homonimia hace difícil reconstruir la red familiar y dificulta la identificación de los personajes, a lo que se suma la movilidad de algunos de sus miembros, que se desplazaban entre Valencia y Mallorca en función de sus estrategias mercantiles o aprovechando una doble ciudadanía, como se ve en otras familias de conversos que se movían entre Valencia y la isla ${ }^{16}$.

Es posible que el abuelo Gabriel procediera del ámbito de los corredores, si bien sus hijos se dedicaron a la actividad mercantil. Pudo tener cuatro hijos, de los cuales uno, Manuel, falleció joven, y otro Gabriel

15 Vid. José Hinojosa Montalvo, En el nombre de Yaveh. La judería de Valencia en la Edad Media (Valencia: Ajuntament, 2007) págs. 350-351.

16 Vid. Enrique Cruselles Gómez, Los mercaderes de Valencia en la Baja Edad Media (1380-1450) (Lleida: Milenio, 2001) pág. 66. 
casó con Raimunda, engendrando -al menos- cuatro hijos varones: Gabriel, Manuel, Francesc y Lluís, $s r$.

El primogénito Gabriel de Bellviure casó con Violante, fruto de cuyo matrimonio fueron Lluís, $j r$., Pere y Jaume Bellviure, todo ello en el período entre 1423 y 1451, según la documentación notarial ${ }^{17}$. Este Pere fue el padre de Violante, la novia buscada para Gonzalo García de Santa María.

\section{Las aCtividades Laborales de los Santa María y los BELLVIURE}

Tras el bautismo forzoso de finales del siglo xIV y primeras décadas del Xv, la mayoría de los conversos siguieron desempeñando sus profesiones de la etapa judía, dado que su integración en la sociedad cristiana en esta primera generación fue gradual. Los cambios fueron más rápidos entre las élites en la segunda y tercera generación, la que ahora nos ocupa, en particular en el ámbito mercantil, cuando ya las referencias a su condición de neófitos han desaparecido de la documentación. En Zaragoza, como en Valencia, abundaron las familias de mercaderes, como los De la Caballería, los Ejea, los Roda, los Santa Pau, etc., que compaginaron el comercio con la compra de censales y la inversión en rentas.

La estrategia profesional de la familia Santa María se caracterizó por su presencia en sectores destacados de la sociedad de cristianos viejos con amplia movilidad entre sus miembros, donde el primer bautizado, Tomás García de Santa María, que fue médico del arzobispo de Zaragoza, igual que lo había sido de judío, mientras que su hijo Gonzalo García de Santa María ejerció como mercader, participando en compañías, como la formada en 23 de noviembre 1433 junto con los conversos y judíos el mercader Jaime Melero, Juan de Lobera. Gento Abez, alias Alagón y Abraham Abempasat para el arriendo de la sisa del vino de la

17 Vid. Cruselles Gómez, Los mercaderes de Valencia en la Baja Edad Media, págs. 122-123. 
aljama judía de Zaragoza ${ }^{18}$. Sabemos que participó también en la compra de censales, arriendos, etc., lo que le permitió acumular un notable patrimonio numerario. Médico, mercader o jurista eran profesiones que permitían la integración en plano de igualdad de esta familia conversa con las de la sociedad dominante.

En cambio, los Bellviure valencianos de segunda y tercera generación, y los que les siguieron, fueron todos mercaderes, profesión que se transmitía en el seno familiar, pasando los negocios de padres a hijos, como fue el caso de Gabriel de Bellviure y sus hijos Manuel, Gabriel junior y Lluís ${ }^{19}$.

Los Bellviure desplegaron su actividad mercantil por las principales rutas del comercio internacional de la Valencia del Cuatrocientos, desde el norte de África y Mallorca a Flandes. Fue habitual que los hermanos Pere y Lluís de Bellviure realizaran operaciones conjuntas, sobre todo desde la muerte de su padre (mayo de 1464), el también mercader Gabriel de Benviure, haciéndose cargo de las deudas pendientes al ser sus herederos universales, como, por ejemplo, las 543 libras y 13 sueldos que Francesc Miró, tendero de Valencia, les dio el 19 de marzo de 1465, suma restante debida a Gabriel por ropas y mercaderías compradas en Brujas ${ }^{20}$.

Tanto los Santa María como los Bellviure, ciudadanos de prestigio, invirtieron parte de sus capitales en deuda pública, como una inversión empresarial rentable y segura. Los municipios emitieron deuda pública a través de la venta de censales consignativos, en los que los comerciantes más distinguidos invertían sus capitales. A ellos se añadían los censales privados. Estos instrumentos crediticios - censales y violarios- fueron utilizados por todos los grupos sociales, urbanos o rurales, sobre todo por la oligarquía ciudadana, y no solo sirvieron para reproducir el patrimonio y obtener unos beneficios, sino que pasaban a formar parte

18 Vid. Lozano Gracia, Las élites en la ciudad de Zaragoza a mediados del siglo $X V$, pág. 214.

19 Vid. Cruselles Gómez, Los mercaderes de Valencia en la Baja Edad Media, págs. 88 y $122-123$.

${ }^{20}$ APRCCC, Protocolos de Dionís Cervera, núm. 24.011. 
de las dotes o legados testamentarios, como veremos en detalle al analizar las capitulaciones matrimoniales ${ }^{21}$.

\section{LAS ALIANZAS MATRIMONIALES}

El matrimonio entre los hijos de los Santa María y los Bellviure permitió a ambas familias crear nuevas relaciones sociales y económicas, unos lazos que -teóricamente- deberían prolongarse en el tiempo, aunque no sabemos si así sucedió realmente. Socialmente ambas estirpes alcanzaron la posición más elevada en la sociedad civil urbana y tuvieron la condición de ciudadanos de Zaragoza y Valencia, respectivamente. Es más, Pere de Bellviure es calificado en un documento de 1480 como «magnificus». La diferencia entre ambas familias es que Gonzalo Santa María ocupó puestos de responsabilidad en la vida pública de Zaragoza, en tanto que los Bellviure nunca ejercieron cargos públicos, integrándose en la categoría subalterna del patriciado, como la calificó E. Cruselles ${ }^{22}$.

Aunque desconocemos los orígenes precisos de la fortuna de los Bellviure, en lo referente al padre de la novia, Pere de Bellviure, es evidente que procedía de sus actividades económicas, sobre todo la

21 Para el reino de Aragón y en torno al censal pueden consultarse: María Luisa Ledesma Rubio, «La hacienda municipal de Zaragoza en el año 1442», en Suma de estudios en homenaje al Dr. Canellas (Zaragoza: Universidad. Facultad de Filosofía y Letras, 1969) págs. 671-687; Antonio Berenguer Galindo, Censal mort. Historia de la deuda pública del Concejo de Fraga (siglos XIV-XVIII) (Huesca: Ayuntamiento de Fraga, 1998); José Ángel Sesma MuÑoz, La Diputación del reino de Aragón en la época de Fernando II (Zaragoza: Institución Fernando el Católico, 1977). Para el reino de Valencia, veánse, entre otros, Francisco Javier Cervantes Peris, «La receptoría general del antiguo patrimonio de María de Luna. La gestión de la deuda censal en unos estados feudales del siglo Xv valenciano», Pedralbes. Revista d'Història Moderna 13-II (1993) págs. 249-254; Antoni Furió, «Crédito y endeudamiento: el censal en la sociedad rural valenciana (siglos XIV-Xv)», en Señorío y feudalismo en la Península Ibérica (ss. XII-XIX), coords. Eliseo Serrano Martín y Esteban Sarasa Sánchez (Zaragoza: Institución Fernando el Católico, 1993) vol. 1, págs. 501-534; Juan Vicente García Marsilla, Vivir a crédito en la Valencia bajomedieval. De los orígenes del censal al endeudamiento del municipio (Valencia: Universitat de València, 2002), y Arcadi GARcía SANZ, «El censal», Boletín de la Sociedad Castellonense de Cultura XXVII (1961) págs. 281-305.

22 Vid. Cruselles Gómez, Los mercaderes de Valencia en la Baja Edad Media, pág. 328. 
mercantil y la censalista, que le habían permitido acumular un importante capital. No cabe duda que nuestro personaje era rico, muy rico podríamos decir. Así lo vemos en 1488, diez años después de celebrarse las capitulaciones matrimoniales, al confeccionarse la tacha de 20.000 libras entre los conversos valencianos para solicitar el edicto de gracia (suma que equivalía al arriendo de dos años de los peajes del reino) apreciándose que los conversos más ricos eran Lluís Esparça, doctor en leyes y sus hermanos, tasados en 36.000 sueldos, y Pere Bellviure, mercader, con 20.000 sueldos. Luego le seguían Gabriel Çabata con 17.000 sueldos y otros con cantidades menores. La contribución a la tacha se calculó a prorrata del nivel de fortuna personal ${ }^{23}$.

Recordemos que entre las dos familias más ricas, los Esparça y los Bellviure, existieron fuertes lazos de todo tipo, económicos y familiares. Así, por ejemplo, en mayo de 1484 Manuel Sparça, mercader, era el tutor y procurador asignado por el Justicia civil de Valencia, de Joana Gracia de Bellviure, hija de Daniel de Bellviure, mercader, en ausencia de su padre. Era también la heredera de todos los bienes y derechos del discreto Manuel Esparça, notario, difunto.

En cuanto a los Santa María, los negocios de Gonzalo, el padre del novio, personaje destacado entre los ciudadanos honrados de Zaragoza, también revelan un alto nivel económico, visible en las donaciones prenupciales y la dote otorgada a su hijo, Gonzalo de Santa María, como luego veremos.

Esta sólida posición económica y social era esencial a la hora de planificar las estrategias matrimoniales, sobre todo cuando se trataba de casar al primogénito. En el grupo converso aragonés la política matrimonial del siglo XV no presenta al principio diferencia respecto a la de los judíos, buscando establecer relaciones familiares dentro de los círculos de familias conversas de similares patrimonios y, si era posible, profesiones ${ }^{24}$. En Aragón, esta tendencia se quebraría, en parte, a lo largo de la segunda mitad de la centuria, ya en la segunda y tercera generación de neófitos, con los hijos primogénitos de las familias más prestigiosas,

23 Vid. Jacqueline Guiral, «Convers à Valence à la fin du XVe siécle», Mélanges de la Casa de Velázquez XI (1975) págs. 81-98.

24 Vid. Encarnación MARín PADILla, «Relacion judeoconversa durante la segunda mitad del siglo xv en Aragón: matrimonio», Sefarad 42 (1982) págs. 243-298. 
al casarse con mujeres de ascendencia cristiana y, si era posible, del estamento nobiliario, lo que facilitaría el acceso a importantes cargos municipales ${ }^{25}$.

Se ha insistido hasta la saciedad en que el matrimonio no era un asunto personal, sino de toda la familia que, bajo la dirección de los padres y con el concurso de todos los parientes, se ponían a buscar la persona -y la dote- adecuada para el/la candidato/a, lo que a veces obligaba a buscarlo fuera de la propia ciudad o incluso del reino. Había que «cassar et collocar segunt su stado e manera, bien e honradamente» a los hijos o hijas, lo que hacía que se conjugara la endogamia con la exogamia. El matrimonio era un elemento esencial a la hora de reproducir el patrimonio familiar, por lo que no se podía dejar al azar ni a la voluntad del individuo, sino que formaba parte de una estrategia colectiva, tal como aparece en los contratos notariales de dote: «de expresso assensu et voluntate nonnullorum parentum et amicorum meorum...». Parientes y amigos eran, por tanto, consultados a la hora de planificar la estrategia matrimonial ${ }^{26}$.

El derecho canónico establecía la edad mínima para el matrimonio en los 12 años para las mujeres y los 14 para los hombres. La mayoría de las mujeres se casaban jóvenes, incluso en plena adolescencia, entre los dieciocho y los veinte años, como propugnaba Francesc Eiximenis en su Llibre de les dones, aunque en Lo Crestià aconsejaba a los padres que las casaran a los catorce años. Para los jóvenes la edad del matrimonio se situaba entre los 20 y los 25 años, tras acabar su aprendizaje laboral, e incluso más tarde, los treinta, entre los mercaderes.

Entre las familias poderosas, el matrimonio era un negocio, en el que se unían fortunas como una forma de inversión más de cara al futuro, por lo que convenía evitar cualquier riesgo, del que no se estaba exento. El matrimonio era la vía para consolidar la fuerza y mantener el control en el seno de la comunidad, a través de una estudiada estrategia de lazos

25 Vid. Miguel Ángel Motis Dolader, «Linajes conversos en el reino de Aragón», Trébede: Mensual aragonés de análisis, opinión y cultura 68 (2002) págs. 75-81: 79, y Lozano Gracia, Las élites en la ciudad de Zaragoza a mediados del siglo XV, pág. 351.

26 Vid. María del Carmen García Herrero, «Las capitulaciones matrimoniales en Zaragoza en el siglo Xv», En la España medieval V:1 (=Estudios en memoria del profesor D. Claudio Sánchez Albornoz [Madrid 1986]) págs. 381-398. 
de parentesco con las otras familias de esta oligarquía, que aumentaban su prestigio y poder. De ahí la importancia de establecer enlaces con miembros del propio grupo socio-profesional, como es nuestro caso ${ }^{27}$.

A la hora de contraer matrimonio se podía acudir a los corredores matrimoniales que solía haber en las grandes ciudades. La persona de confianza encargada de las negociaciones matrimoniales recibía un documento notarial de procuración, la «procura ad contrahendum matrimonium», que no aparece en el matrimonio del que nos ocupamos.

En el contrato matrimonial las familias acordaban todos los detalles en torno a la nueva unidad familiar, de forma que permitieran la reproducción del grupo. En el pacto son esenciales los aspectos económicos, pero también la residencia, como veremos en el matrimonio entre Gonzalo y Violante, un asunto que fue fuente de conflicto entre las partes. Estos contratos responden a unos modelos de formularios notariales, que se inician siempre con invocaciones religiosas, que en este caso son: «In Dei nomine et eius divina gracia. Amen», en la donación de bienes hecha por Gonzalo García de Santa María a su hijo, o «In Christi nomine eiusque gloriose genitricis, et cetera», en el de las capitulaciones dotales de Violante ${ }^{28}$.

El matrimonio tenía un coste económico, que quedaba reflejado minuciosamente en las cartas dotales, en las que las dos familias dotaban a la pareja de una serie de bienes, que eran especificados de forma ge-

27 Sobre el matrimonio en Aragón, aparte del citado García Herrero, «Las capitulaciones matrimoniales en Zaragoza en el siglo XV», vid. María del Carmen García Herrero, Las mujeres en Zaragoza en el siglo XV (Zaragoza: Ayuntamiento, 1990) y «Matrimonio y libertad en la Baja Edad Media aragonesa», Aragón en la Edad Media XII (1995) págs. 267-286. Para el reino de Valencia, vid. Cruselles Gómez, Los mercaderes de Valencia en la Baja Edad Media, págs. 278-291; Honorio García y GARCÍA, «Estudios de Derecho Foral Valenciano: El consentimiento de la esposa para el matrimonio», Boletín de la Sociedad Castellonense de Cultura XVII (1936) págs. 357-363; Miguel Gual Camarena, «El régimen matrimonial en los Fueros de Valencia», Anuario de Historia del Derecho Español XXXVII (1967) págs. 553-561, y Jaime. Piqueras JUAN, «Estratificación social y matrimonio en el siglo XV valenciano: una visión sobre las comarcas del norte de Alicante», Anales de la Universidad de Alicante. Historia Medieval 17 (2011) págs. 445-468.

28 Vid. José Luis LaCruZ BerdeJo, «Capítulos matrimoniales y estipulación capitular», en Centenario de la Ley del notariado, vol. II (Madrid: Consejo General del Notariado, 1962) págs. 1-58, y María del Carmen BAyod López, Sujetos de las capitulaciones matrimoniales aragonesas (Zaragoza: Institucion Fernando el Católico, 1995). 
neral o minuciosamente. El régimen dotal en el matrimonio foral valenciano estaba constituido por la aportación de la mujer en concepto de dote (exovar), y una contradote del marido (creix), lo que establecía entre los esposos una interrelación de carácter económico muy concreta, que coexistía con los patrimonios particulares de cada cónyuge.

La dote era un elemento esencial a la hora de formar una nueva familia y en las familias mercantiles, tanto de Zaragoza como de Valencia en el matrimonio entre Gonzalo y Violante, la dote estaba compuesta por dinero en efectivo y capital invertido en censales, joyas, y otros bienes, entre ellos los inmuebles. Son un buen indicador del patrimonio disponible por las familias de los contrayentes.

Los estudios sobre las dotes en las que intervenían los mercaderes valencianos muestran un amplio espectro, que iba desde los 19.000 sueldos a los 800 , con una media de 3.900 sueldos que solo se superaba en el 43,55\% de los 56 contratos estudiados, acorde con el distinto nivel de fortuna personal ${ }^{29}$. Estas cifras fueron superadas en el caso del enlace entre un Santa María y una Bellviure, en el que la novia aportaba 60.000 sueldos y el novio otros 30.000 de aumento y 5.000 más graciosamente. Es importante destacar estas cantidades, ya que como ha señalado Susana Lozano al analizar las dotes de los ciudadanos honrados de Zaragoza, la dote más alta que encuentra en este siglo son precisamente los 55.000 sueldos que el mercader y ciudadano Gonzalo de Santa María ofreció a su hija Beatriz, hermana de Gonzalo, el futuro marido de Violante, en el matrimonio estipulado el 7 de octubre de 1460 con el caballero Ramón Cerdán, cifra que superaba otras dotes en matrimonios incluso en el grupo nobiliario. La potencia económica del mercader Santamaría era, sin duda, enorme, para poder aportar como dote de los dos hermanos, nada menos que 90.000 sueldos, lo que le permitió, además, emparentar con la nobleza del reino.

La dote iba acompañada del creix o escreix, institución foral que designa las donaciones complementarias de la dote hecha por el marido a la mujer con ocasión del matrimonio ${ }^{30}$.

29 Vid. Cruselles Gómez, Los mercaderes de Valencia en la Baja Edad Media, pág. 271.

30 Vid. María Ángeles Belda Soler, Contribución al estudio de las instituciones del derecho histórico valenciano. El régimen matrimonial de bienes en los "furs" de 
Los esponsales, realizados ante notario, eran la promesa mutua de matrimonio que se hacían y aceptaban el hombre y la mujer, llevada a cabo en forma requerida por la ley. En el derecho foral valenciano era uno de los requisitos que podían preceder al matrimonio, pero su celebración no era esencial para la validez de este.

Desconozco cuáles fueron los vínculos y relaciones que hubo entre los Santa María y los Bellviure previas a la planificación del presente matrimonio, ya que ninguna documentación nos ha llegado sobre ello. Dado que ambos padres Gonzalo García de Santa María y Pere de Bellviure eran mercaderes todo apunta a posibles relaciones y operaciones mercantiles conjuntas, aunque ello no pasa de ser una hipótesis.

¿Por qué Gonzalo decide buscar una esposa en Valencia y no en Zaragoza? Hay algo que conviene no olvidar, y es que primero los judíos y luego los conversos zaragozanos y valencianos mantuvieron frecuentes relaciones desde la conquista de la ciudad de Valencia por Jaime I, y no en vano las constituciones de la aljama de Valencia fueron al principio las de Zaragoza, según disposición de Jaime I. En Valencia encontramos en el siglo XV conversos de origen aragonés de las poderosas familias Cavallería, Sánchez o Santángel, por citar las más conocidas, que mantenían negocios y vínculos entre las dos capitales. Es evidente que Gonzalo García de Santa María, a la hora de buscar una esposa para su hijo Gonzalo, haría previamente todas las gestiones oportunas en Zaragoza o donde considerara oportuno, hasta inclinarse por la familia Bellviure, con la que ya mantenían -suponemos- relaciones y gozaban de un sólido patrimonio.

Por su parte S. Lozano se planteó el problema de la exogamia de parentesco y la necesidad de buscar fuera de la familia nuevos miembros, señalando que «se deben de entender por otro lado como mecanismos de supervivencia del grupo, en la medida en que logra establecer la alianza con otros grupos familiares». Era también una forma de superar el marco de la consanguinidad entre estas familias de las élites ciudada-

Valencia (Valencia: Editorial Cosmo, 1966), y Honorio GARCía y GARcía, «Más sobre el "creix" y el "exovar"», Boletín de la Sociedad Castellonense de Cultura VIII (1927) págs. 29-32, 250-253 y 316-318 y «Estudios de Derecho Foral Valenciano. Derechos de la viuda indotada», Boletín de la Sociedad Castellonense de Cultura XII (1931) págs. 22-26. 
nas, lo que hizo que familias conversas, como los Santángel o los Santa María, establecieran alianzas matrimoniales con las de otras ciudades de la Corona de Aragón, en este caso Valencia.

Aunque en la generación de nuestros protagonistas en el grupo converso de Zaragoza y Valencia alternaran los matrimonios endogámicos y exogámicos,

la preferencia endogámica se aplica en un orden de importancia variable según la capacidad económica, la formación, el oficio y la posición profesional, la condición jurídica, la identidad religiosa, la procedencia, las cualidades morales o la edad o incluso el prestigio social ${ }^{31}$.

También hay que tener presente la endogamia profesional en las alianzas matrimoniales, como eran los mercaderes, situación que se dio en Zaragoza y en Valencia. Aquí, el porcentaje de los esposos que contrajeron matrimonio con la hija de un profesional de su mismo oficio fue del $73,3 \%$ y de $74,4 \%$ en los mercaderes ${ }^{32}$.

La primera noticia que conozco sobre la proyectada boda entre Gonzalo García de Santa María, jurista de Zaragoza, con Violante, hija de Pere de Bellviure, mercader de Valencia, fue la donación que el 13 de abril su padre, Gonzalo García de Santa María, mercader de Zaragoza, le hizo de diversos bienes cara al futuro matrimonio. Esta tuvo lugar en la localidad de Juslibol, a orillas del río Ebro («ripe fluminis Iberi regni Aragonum»). El documento es una «donatio inter vivos», de padre a hijo, y ofrece gran interés tanto por su contenido intrínseco, ya que servía para fortalecer el nuevo grupo conyugal, como porque a través de él podemos conocer la solvencia y una parte del patrimonio de este notable mercader converso, en este caso centrado en censales abonados por el General del reino de Aragón, en arriendos en Calaceite, casas en Zaragoza y una alquería en la huerta de Zaragoza, con campos de viñedo y otras tierras, que nos proporcionan además interesantes datos sobre la toponimia bajomedieval zaragozana. Veámosla con detalle.

31 Vid. Lozano Gracia, Las élites en la ciudad de Zaragoza a mediados del siglo $X V$, pág. 359 .

32 Vid. Cruselles Gómez, Los mercaderes de Valencia en la Baja Edad Media, págs. 278-282, y Lozano Gracia, Las élites en la ciudad de Zaragoza a mediados del siglo $\mathrm{XV}$, pág. 358 . 
En la donación, Gonzalo García de Santa María, mercader de Zaragoza, libremente y sin coacción, ante el próximo matrimonio de su hijo Gonzalo García de Santa María, doctor en leyes, como seguridad de la dote («pro securitate dotis per ipsam Yolante er eius patrem») y por aumento de la dote de la citada Violante, así como para sustentar dicho matrimonio («pro sustentaciones honorum prefixi matrimonium») y constituir un patrimonio para los hijos e hijas que nazcan del mismo le entregaba diversos bienes y acciones especificados en el documento. La donación a su hijo en censales y bienes fue la siguiente:

En primer lugar, 2.000 sueldos jaqueses censales anuales, tanto en propiedad como en pensiones, de aquellos que le abona el General del reino de Aragón cada año el 8 de febrero, bajo cierta pena. Correspondían a aquellos 4.000 sueldos censales que Ramón de Casaldávila, síndico y procurador del General de Aragón, vendió a Pelegrino de Jasa, jurisconsulto de Zaragoza y maestre racional del reino de Aragón por el precio de 15.000 sueldos por millar, es decir 60.000 sueldos. El documento fue firmado por Antonio de Aldonera, notario, difunto, de Zaragoza, el 8-2-1424 y lo ratificó luego Antonio de Salavert, difunto, notario, regente la escribanía del Justicia, el 10-5-1424. Posteriormente, estos 4.000 sueldos fueron vendidos a Catalina Díaz de Aug, viuda de Eximén Aznar, difunto, jurisconsulto de Daroca, quien a su vez hizo donación de los mismos el 14-12-1433 en documento redactado ante Domingo Aznar, notario, difunto, de Romanos, aldea de Daroca, a Fabián de Rabaneda, Justicia de Daroca y confirmado el 6-3-1434 ante Nicolás del Vilar, notario, difunto, de Daroca. El censal pasó más adelante, con todos sus derechos, a Juan Díaz de Aug, quien, junto con sus hermanos, vendió a Gonzalo García de Santa María y los suyos 2.000 sueldos censales por el precio de 30.000 sueldos jaqueses, según documento hecho el 19-3-1451 ante Pedro Sanchiz, notario de Calatayud, difunto.

Seguían otros 1.000 sueldos censales en propiedad y en pensiones que le abonaba el General de Aragón el uno de septiembre. Este censal se lo vendió a los diputados del General de Aragón Juan de Moriello, caballero, habitante en Sariñena, por 15.000 sueldos, según documento hecho el 5-9-1436 por Antonio de Aldonera, notario, difunto, y ratificado por el Justicia de Aragón, en documento del 26-11-1436 ante Pedro Torres, notario, también fallecido. Luego estos 1.000 sueldos fueron 
vendidos por Juan de Moriello a Juan de Mur, de Zaragoza, por 15.000 sueldos, el 25-3-1437 ante el notario Alfonso Francés, difunto. El 17 de junio de ese año Juan de Mur los vendió a Gaspar Ruiz, mercader de Zaragoza, fallecido, por el mismo precio, según documento hecho el 28-10-1439 ante el notario Pedro Sánchez de Calatayud, difunto. Hubo una nueva venta del citado censal a cargo de Gaspar Ruiz a Pedro García de Santa María, abad de san Millán de Lara en Burgos, hermano del otorgante. Tras su muerte y de acuerdo con el derecho aragonés, todos sus derechos pasaron a Gonzalo García de Santa María y su hermano Juan García de Santa María. Este renunció a sus derechos en favor de Gonzalo el 9-3-1443 ante el notario Miguel de Gurrea, difunto, de Zaragoza, poseyendo ahora dicho censal de pleno derecho.

El donante entregaba a su hijo los derechos y acciones que le correspondían en Calaceite por título de arriendo contra todos los vecinos, vasallos y habitantes en dicho lugar y su término, que poseía junto con el capítulo de la catedral de Tortosa, de todas las rentas y frutos que le correspondían por el plazo de los 34 años próximos en dicha localidad, resto de los 44 años por los que había arrendado los derechos del tercio diezmo y la octava parte de los frutos y espeltas, molinos, hornos, aceite, trigo, carnicerías, tejerías, herrenales, censo del morabatino y otros en dicho lugar y término. Dicho arriendo y los acuerdos se firmaron con Miquel Solà, notario de Tortosa, en Calaceite el 10-8-1467, de acuerdo con la sentencia arbitral dada por Isabel de Urrea y de Mur y Pedro Savertés, jurisconsulto de Tortosa, y por Jaume Rius, notario de Tortosa, el 11-6-1368 y por otros capítulos de la catedral de Tortosa y los vasallos de Calaceite, de un lado, y el citado Gonzalo García de Santa María, del otro.

Concedía a su hijo todos los derechos de arriendo que le pertenecían en el lugar de Calaceite y su término, así como todas las acciones contra dicho lugar, sus vasallos, vecinos y habitantes por razón de censales u otros derechos adquiridos de ese lugar y su término, así como de sus habitantes y vecinos.

Así mismo, le daba unas casas suyas, francas de toda carga y servidumbre, que poseía en la parroquia de San Pedro de Zaragoza, en la calle de Las Boticas Fondas, con todos sus bienes muebles y semovientes, ropa, joyas, plata, vajilla de plata, ganado, bestias de cabalgar y 
otras, y los demás bienes que hubiere, con las bodegas contiguas a dichas casas, incluidos los cubos, tinajas, vasos, jarras, etc., de madera, de alfarería o de otros materiales que allí había. El inmueble lindaba con casas de los herederos de Juan Pérez de Caseda, con casas de Pedro Fernando de la Cavallería y sus hermanos, que eran de Guillermo Dezquer y con un callejón sin salida, así como con la calle.

Otra de las donaciones fue la de una alquería o torre («alqueriam sive turrim») franca, en la huerta de Zaragoza, en la partida llamada el Término de Manblás, con toda las vasijas que allí había para guardar trigo y aceite, y las restantes cosas que hubiera en la alquería. Le otorgaba las viñas, majuelos y tierras que poseía en dicha alquería, que abarcaban veintidós cahizadas de tierra, a medida de Aragón, francas, salvo dos cahizadas que tenían bajo dominio directo las religiosas y la priora del monasterio del Sepulcro, de Zaragoza. Por la parte inferior de esta tierra pasaba una acequia, llamada vulgarmente la acequia Durdán, que iba al río Gállego, lindando con dicha acequia, con viña y con tierra campa de Martín de Añón, abonando un censo de cinco sueldos jaqueses anuales, pagaderos a san Juan. Los límites de la alquería y el campo eran la citada acequia Durdán, el camino que iba al lugar de Peñaflor, pared por medio con la viña y con otra tierra campa por medio de la cual atravesaba un camino que iba desde Zaragoza a la alquería llamada Montañana y por el cual se podía ir desde dicha alquería al lugar de Villamayor, lindando con el camino que iba a Peñaflor y con la alquería o torre de Montañana.

Estas donaciones se hacían con una serie de condiciones:

En primer lugar, el donante, Gonzalo, el padre, conservaba el derecho de administrar las casas y torre con sus tierras contiguas mientras viviera, pero sus frutos y emolumentos serían de su hijo.

Durante toda su vida podría vivir libremente con su esposa y familia en dicha torre sin ninguna prestación. La donación quedaría sin efecto si el citado matrimonio con Violante de Bellviure no se llevara a cabo. En el caso de que su hijo falleciera sin hijos naturales o si los hubiera y estos lo hicieran antes que el donante, Gonzalo García de Santa María, padre, toda la donación antes citada pasaría a sus herederos.

Gonzalo era un personaje muy bien relacionado con la jerarquía política y social de Aragón, por lo que, con el fin de darle mayor solemnidad y garantías legales a la presente donación, quiso que estuviera 
presente el Justicia del reino de Aragón y zalmedina de la ciudad de Zaragoza junto con sus oficiales, según estipulaban los fueros, observaciones y prácticas forales, y el escudo de Aragón.

Como fiador de la presente donación, y tal como estipulaban los fueros del reino, dejó a Pedro de Maya, escudero, habitante de Zaragoza, junto con él mismo, obligándose en sus personas y bienes a cumplir lo dispuesto en la presente donación. Como testigos actuaron Juan de Santángel, profesor de leyes de Zaragoza, y Andreu Climent, mercader de Tortosa ahora residente en Zaragoza por negocios.

A continuación se redactó otro documento por el padre, Gonzalo García de Santa María, realizado el mismo día, en el que exponía que la anterior donación de bienes sería tras su muerte, no antes, cediendo a su hijo los derechos que tenía contra particulares y universidades por cualquier causa o motivo, reteniendo para sí la suma de 100.000 sueldos jaqueses, con los que podría hacer su libre voluntad, quedando sin efecto la donación si el matrimonio no tuviera lugar.

El 24 de abril el novio, Gonzalo García de Santa María, doctor en leyes, desde su alquería en la partida de Manblás, en la huerta zaragozana, nombró procuradores generales a Gizberto de Tolosa, mercader de Valencia, y Andreu Climent, mercader de Tortosa, ahora en Zaragoza por negocios, para firmar los capítulos matrimoniales y contraer matrimonio en su nombre con Violante, hija de Pere de Bellviure, mercader de Valencia, en los que la futura esposa y su padre aportarían como dote 60.000 sueldos de Valencia en dinero y censales, a razón de 15.000 sueldos por millar. La procuración incluía también el poder para incrementar la dote con 30.000 sueldos de Valencia en concepto de virginidad de la novia, a los que se añadirían otros 5.000 como gracia especial en bienes y derechos del novio, totalizando 35.000 sueldos.

Si Violante falleciera habiendo tenido hijos legítimos de este matrimonio podría disponer libremente de dicha suma a su voluntad. Si el matrimonio se disolviera, Violente dispondría de una habitación de los bienes de Gonzalo con todo su equipamiento, con los mejores paños que hubiera.

En caso de disolución del matrimonio por viudedad dispuso que se le entregaran a Violante de los bienes de Gonzalo la parte que le correspondiera, y mientras siguiera viuda que ella con los hijos del matrimonio 
pudiera residir y poseer las casas mayores que tenía (Gonzalo) en la parroquia de San Pedro de Zaragoza, en la calle de las Botigas Fondas.

El procurador estaba también autorizado para jurar en nombre de Gonzalo el compromiso acordado de residir en la ciudad de Valencia, así como cualquier otro capítulo oportuno que se pudiera añadir para mejorar dicho matrimonio.

El documento de procuración, para garantizar el aumento de la dote a Violante, aseguraba las mencionadas casas y los tres mil sueldos jaqueses que le abonaba de pensión censal el General de Aragón, de ellos dos mil el ocho de febrero y mil el uno de septiembre, además de la alquería en la huerta de Zaragoza, los derechos y rentas que le pertenecían en Calaceite, así como los demás bienes que su padre le dio para dicho matrimonio, disponiendo que los poseyera Violante de Bellviure como dote y aumento. Todo ello no podría recuperarlo ella o sus herederos hasta que hubiera pasado un año tras la disolución del matrimonio.

Dado que estamos ante un matrimonio por poderes, los procuradores dispondrían de atribuciones para contraer matrimonio en nombre del otorgante, Gonzalo García de Santa María, y consentir dicho matrimonio de palabra y como esposo legítimo de Violante, que pasaría a ser esposa de Gonzalo. Se les autorizaba a prestar juramento y consentir dicho matrimonio y hacer todo lo necesario para que tuviera efecto de derecho $\mathrm{y}$ de hecho.

Aunque los procuradores nombrados fueron dos, lo cierto es que las negociaciones con el padre de la novia, Pere de Bellviure, las llevó a cabo Gispert de Tolosa, mercader converso de Valencia, casado con Leonor, que en abril de 1480 emparentó por vía matrimonial con Pere de Bellviure. El día 20 de este año se firmaron las capitulaciones matrimoniales de su hija Isabel con Gabriel de Bellviure, hijo de Pere de Bellviure, aportando como aumento de la dote la suma de 30.000 sueldos. De ellos 20.000 sueldos los entregará cinco días antes de que se celebrara la boda en la iglesia, en dinero o en censales, y los otros 10.000 en el plazo de los cinco años siguientes a la celebración de las nupcias en dinero o censales, obligando para ello sus bienes muebles. En esta dote incluye los 7.000 sueldos que el citado padre debía entregarle a su hija Isabel por causa de la dote de su madre Leonor. Gabriel de Bellviure la aceptó y la incrementó con otros 15.000 sueldos como estipulan los 
fueros. Total 45.000 sueldos $^{33}$. Estamos pues, ante un destacado mercader con una notable capacidad económica, como refleja el incremento de la dote de su hija, justo la mitad que la de Pere de Bellviure, que fue de 60.000 sueldos, igual que la de Violante, que vemos a continuación.

En efecto, el 13 de mayo de 1478 se firmaron en Valencia las capitulaciones dotales del próximo matrimonio a celebrar entre los ya citados Violante, hija de Pere de Bellviure y de su difunta esposa, Brianda, con Gonzalo García de Santa María, doctor en leyes, hijo de Gonzalo García de Santa María, mercader. Eran estas:

1. ${ }^{\circ}$ Pere Bellviure aportaba una dote para su hija valorada en 60.000 sueldos, en los que se comprendían los 15.000 sueldos y todo el derecho a ella perteneciente contra su padre Pere Bellviure por la dote de su difunta madre Brianda o por otra causa.

2. Dicha suma se entregaría un día antes de celebrarse la misa en la iglesia, y de ella 45.000 sueldos lo serían en censales comprados en el reino de Valencia, y otros 5.000 sueldos en joyas, oro y piedras preciosas, según tasación de Gisbert de Tolosa. De los restantes 10.000 sueldos Bellviure transportaría a Gonzalo mil florines de Sicilia, que el rey de Castilla tomó de un cambio de Pere Bellviure y de su hermano Lluís Bellviure. La dote se constituía a Fuero de Valencia con la condición de que si Violante falleciera sin hijos en ese caso los 60.000 sueldos regresarian sin disminución alguna a Bellviure, si viviera, o a sus herederos.

3. ${ }^{\circ}$ Si el citado micer Gonzalo en virtud de la cesión de los 10.000 sueldos de dicho cambio no los hubiera recibido en el plazo de cinco años después de la misa matrimonial, en ese caso Pere Bellviure se los abonaría en dinero o en censales, sin interés alguno.

4. ${ }^{\circ}$ El citado Gonzalo, según fuero de Valencia aplicable a las vírgenes, aportaría como aumento de la dote 30.000 sueldos, además de otros 5.000 de forma graciosa, contabilizando entre dote

33 APRCCC, Protocolos de Manuel Esparça, núm. 11.382. 
y aumento 95.000 sueldos, pudiendo Violante disponer de ellos como quisiera o dejarlos a sus hijos legítimos.

5..$^{\circ}$ Un aspecto importante en las capitulaciones era el referente a la residencia, y en este caso se dispuso que Violante tendría de los bienes de su marido una habitación y toda la ropa de cama adornada, colchas y sábanas y cortinajes que se encontrara en casa del citado micer Gonzalo cuando falleciera este, además de telas de raso y de pies y cofres, «segons és mester per a una cambra honradamente conreada», pudiendo disponer libremente de ellos, con o sin marido. Mientras permaneciera viuda podría residir en la casa del citado Gonzalo, que había recibido en donación.

6..$^{\circ}$ Todos esta dote y aumento los aseguraba Gonzalo sobre sus bienes, casa, alquería, bienes censales, su casa y rentas del lugar de Calaceite dados a su hijo el 13 de abril pasado hasta que la citada Violante recibiera íntegramente la dote y el aumento

7..$^{\circ}$ Micer Gonzalo se comprometía mediante juramento, bajo pena de 6.000 florines, a tener su casa y domicilio, junto con su mujer, en Valencia y no cambiaría de residencia ni permitirá que ella lo hiciera, al menos en seis años desde la celebración de las nupcias.

8..$^{\circ}$ Se dispuso que cuando Gonzalo viniera a Valencia el día que se casara con Violante aprobaría y firmaría estas capitulaciones en presencia de testigos.

9..$^{\circ}$ Así mismo, Gonzalo se comprometía a venir a Valencia durante el próximo mes de julio, bajo la pena de 10.000 florines, y en caso de no hacerlo Pere de Bellviure quedaba desligado de todo lo prometido a aquel.

10. Ambas partes se comprometían a observar los capítulos citados, a que se hicieran dos cartas públicas y a que junto a ellos se firmaran cartas nupciales, que no conocemos.

Como era habitual ambas partes juraron dichos capítulos sobre los evangelios y en caso de incumplimiento pagaría una multa de 2.000 florines la parte que no lo respetara, obligándose cada uno con sus respectivos bienes muebles e inmuebles. Como testigos firmaron el maestro 
Alfonso de Bonilla, caballero de Denia, de la casa del conde de Denia; Gonzalo Roiz, doncel y doctor en leyes; Miquel Aparici, presbítero, y Tristan de Leonís, tirador, de Valencia. La moneda utilizada en la negociación fue la valenciana. El documento se redactó en los protocolos de dos notarios valencianos: Manuel de Esparça y Guillem Exernit.

El 22 de mayo Gispert de Tolosa aprobó de nuevo dichas capitulaciones, igual que Pere de Bellviure, aunque este hizo la salvedad de perdonarle la pena contenida en el apartado que le obligaba a venir a Valencia el próximo julio para llevar a cabo el matrimonio, dado que este se había celebrado de palabra.

La siguiente noticia, inserta a continuación de la documentación citada, ya es del 16 de enero de 1480, en que fueron leídos de nuevo dichos capítulos en Valencia y en presencia del notario, de Gonzalo García de Santa María y de Pere Bellviure, siendo aceptados y firmados. Santa María prometió a Bellviure, bajo pena de 6.000 florines, que tendría su domicilio en Valencia con su mujer y familia y no lo abandonaría en el plazo de los seis años estipulados desde que se celebrara la boda. Firmaron como testigos Joan Tolsà, caballero, Bernat Pintor, mercader, habitante en Valencia, y Joan de la Cavallería, ciudadano de Zaragoza ${ }^{34}$.

No sabemos la fecha exacta del matrimonio eclesiástico entre Violante y Gonzalo, pero en un documento del 16 de enero de este año 1480 Pere de Bellviure calificaba a Gonzalo como su yerno («genero meo»), a la vez que varios documentos notariales expedidos ese día lo situaban residiendo en Valencia -tal como estaba acordado-, resolviendo asuntos relacionados con el pago de la dote y de su aumento por ambas partes. Por tanto la boda debió ser en la segunda mitad de 1478 o en 1479. En uno de estos instrumentos notariales Gonzalo García de Santa María, doctor en leyes, a la sazón en Valencia, vendió, según documento hecho en Zaragoza el pasado 28 de diciembre, en su nombre y en el de su padre Gonzalo García de Santa María, a Pedro y Fernando de la Cavallería, ciudadanos de esa ciudad, 1.000 sueldos jaqueses censales por el precio de 15.000 sueldos, que formaban parte de aquellos 2.000 sueldos censales que el General del reino de Aragón le abonaba cada año de sus generalidades el 8 de febrero. Los 15.000 sueldos eran aquellos que en

${ }^{34}$ APRCCC, Protocolos de Guillem Exernit, núm. 23.004. 
su origen Ramón de Casaldavila, entonces síndico y procurador de los diputados del General de Aragón, vendió a Pelegrín de Jasa, jurisconsulto, ciudadano de Zaragoza y maestre racional del reino de Aragón, por el precio de 60.0000 sueldos, tal como ya vimos en la donación de bienes hecha por Gonzalo García de Santa María, mercader, a su hijo ${ }^{35}$.

Parece que la entrega de la dote no estaba saldada por entonces, a pesar de haberse celebrado el matrimonio, y el 1 de agosto de este año 1480 Pere de Bellviure, prometió a Gonzalo García de Santa María, doctor en leyes, su yerno, que en el plazo de seis meses le daría, con el fin de cumplir las capitulaciones matrimoniales, 30.000 sueldos, resto que aún le quedaba por entregar de los 60.000 sueldos de la dote de Violante, y 50 libras de intereses el 31 de julio próximo. Si no abonaba lo debido debería entregar intereses a razón de 5.000 sueldos por mi$11 \mathrm{r}^{36}$.

Ese día Pere de Bellviure, con el fin de abonar los 30.000 sueldos debidos de la dote a Gonzalo García de Santa María, vende a Violante y a su esposo 2.000 sueldos censales, cargados sobre una serie de censales que le abonaban el General del reino de Valencia y diversos particulares, por la citada suma de 30.000 sueldos.

La estancia de Gonzalo García de Santa María en Valencia la aprovechó para nombrar procurador suyo a Pedro de Moya, escudero, con el fin de recibir de Ramón Siscar, caballero de la orden de San Juan de Jerusalén, comendador que fue de Orta, en Cataluña, y de Torrent, en Valencia, las 14 cubas de aceite que le debía y que formaban parte de una deuda del comendador por valor de cien florines a su difunto hermano Pedro García de Santa María.

En otro documento nombró procurador suyo a su padre, el mercader Gonzalo García de Santa María, para que exigiera en su nombre el dinero, ropas y otros bienes que le debían particulares y universidades ${ }^{37}$.

35 APRCCC, Protocolos de Guillem Exernit, núm. 23.004. 16-1-1480, Valencia. Como testigos actuaron Joan Tolsà, caballero, y Gisbert de Tolosa, y Bernat Pintor, mercaderes, habitantes en Valencia.

36 APRCCC, Protocolos de Manuel Esparça, núm. 11.382.

37 APRCCC, Protocolos de Guillem Exernit, núm. 23.004. 16-1-1480, Valencia. 
No sabemos las razones que llevaron a Gonzalo García de Santa María a querer trasladarse a Zaragoza. Lo cierto es que el 19 de septiembre de 1480 reconocía ante el notario que, después de algunas requisiciones hechas ante el Justicia civil de Valencia y los jueces, fue autorizado a llevarse a Violante de Benviure y de Santa María - a destacar que al apellido paterno se ha añadido ahora el del marido-, su esposa, a la ciudad de Zaragoza, a pesar del juramento y las penas impuestas en las capitulaciones matrimoniales, en las que se indicaba expresamente que Gonzalo debía residir seis años seguidos en Valencia tras la boda. Por su parte Gonzalo se comprometió a que Violante regresara a Valencia en el plazo de un año a partir de esta fecha, y que el matrimonio y la familia residirían el plazo estipulado en dichas capitulaciones, bajo la pena de 3.000 florines si no lo hiciera. Con el fin de poder ejecutar dicha pena en caso de incumplimiento Gonzalo nombró procurador a Bernat Saidia Tondia, doctor en decretos en Valencia.

A continuación Violante, de acuerdo con lo arriba estipulado, se comprometió a ir un año a residir en Zaragoza y regresar luego a Valencia, nombrando procurador a su padre, Pere de Bellviure, con el fin de que se cumpliera todo lo acordado ante el notario ${ }^{38}$.

En cualquier caso, el pago de la dote siguió generando tensiones entre ambas familias y el 19 de septiembre de 1480 Gonzalo García de Santa María, que debía una suma de dinero a Luis de Santángel, mercader de Valencia, le cedió los derechos y acciones que tenía contra su suegro, Pere de Bellviure, debidos por la dote nupcial. Se trataba de 2.000 sueldos censales que su suegro le abonaba a medias cada año el último día de los meses de julio y de enero.

El goteo del dinero de la dote prosiguió en años sucesivos, y el 7 de noviembre de 1484 Pedro de Moya, escudero, residente en Valencia por diversos negocios y procurador de Gonzalo García de Santa María, doctor en derecho de Zaragoza, reconoció que Pere de Benviure le dio los 10.000 sueldos que debía entregar a su principal, de un total de 60.000 sueldos, correspondientes a la dote de Violante. Debía haberlos entregado, según dicho documento, durante el mes de enero próximo,

${ }^{38}$ APRCCC, Protocolos de Guillem Exernit, núm. 23.004. 19-9-1480, Valencia. 
por lo que ahora le declaraba absuelto de cualquier obligación con respecto a dicha suma ${ }^{39}$.

Esta es la última noticia encontrada sobre dicho matrimonio, y no sabemos si realmente el matrimonio volvió a Valencia, aunque dada la elevada pena contemplada en caso de no hacerlo, hay que pensar que Gonzalo García de Santa María y su esposa Violante de Bellviure residieron en la ciudad del Turia al menos seis años a partir de septiembre de 1481, aunque tampoco se indica si en esos seis años había que descontar el plazo que ya llevaban residiendo tras celebrarse el matrimonio eclesiástico.

Recibido: $11 / 02 / 2020$

Aceptado: 08/06/2020

39 APRCCC, Protocolos de Guillem Exernit, núm. 23.008. 7-11-1484, Valencia. 


\section{APÉNDICE DOCUMENTAL}

1478, mayo, 13, Valencia.

Capítulos matrimoniales firmados entre Pere de Bellviure, mercader de Valencia, y Gisbert de Tolosa, mercader de Valencia, como procurador de Gonzalo García de Santa María, mercader de Zaragoza, sobre la dote del matrimonio a celebrar entre Violante de Bellviure y Gonzalo García de Santa María, doctor en leyes, de Zaragoza.

APRCCC, Protocolos de Manuel d'Esparça, núm. 11.381.

APRCCC, Protocolos de Guillem Exernit, núm. 23.002.

Die mercurii, $\mathrm{XIII}^{\mathrm{a}}$ mensis madii, anno a nativitate Domini $\mathrm{M}^{\mathrm{o}} \mathrm{CCCC}$ LXXVIII $^{\circ}$

In Christi nomine eiusque gloriose genitricis et cetera.

Nos, Petrus de Bellviure, Mercator, civis civitatis Valencie, ex una, et Gizbertus de Tolosa, mercator, civis civitatis eiusdem, ut procurador magnifici Gondisalvi Garcia de Sancta Maria, legum doctoris, filii magnifici domini Gundisalvi Garcia de Sancta Maria, mercatoris, habitante civitatis Cesarauguste in Aragonum, ad subscripta peragenda legitime constitutus cum publico procuraciones instrumento, acto in eadem civitate Cesaraguste, die XXIIII ${ }^{a}$ mensis aprilis proxime decurso cum amplissime potestate et facultate, recepto per discretum Guillermum Exernit, notario, alterum ex notariis subscriptis ut in eodem clare videtur partibus ex altera, gratis, et cetera, nos, dicte partes confitemur et in veritate recognoscimus una pars nostrum alteri et altera alteri ad invicem et vicisim presentibus et nominibus predictis acceptantibus super matrimonio Deo ducente de proximo fiendo et in facie sancte matris ecclesie celebrando inter magnificam Yolantem, domicella, filiam mei, dictum Petri de Bellviure, et honorabilis Briande, uxor quondam mee legitimam et naturalem, et dictum Gundisalvum Garcia de Sancta Maria, principalem mei, dictum Gisberti de Tholosa, inter nos dictas partes fuerunt atque sunt inserta, concordata, pactata et stipulata capitula in nostri predictarum partium et testium subscriptorum presencia per alterum ex dictis et subscriptis notariis, lecta et publicata tenoris sequentis:

En lo nom de nostre Senyor Déu Jesucrist e de la gloriosa Verge Maria, mare de aquell. Capítols concordats, fets e fermats per lo matrimoni migansant la gràcia de Sperit Sant, fahedor per e entre los magnífichs Yolant, donzella, filla del magnífich en Pere de Bellviure, mercader de València, e de na Brianda, quondam, muller de aquell, de una part, e lo magnífich micer Gonçalbo Garcia 
de Santa Maria, doctor en leys, fill del magnífich don Gonsalvo Garcia de Santa Maria, mercader de la ciutat de Saragoça, habitadors, de la part altra, e en absència del dit micer Gonçalvo fets e fermats per lo honorable en Gisbert de Tholosa, mercader de la ciutat de València, procurador de aquell.

I. Primerament, és convengut, pactat e concordat entre les dites parts que lo dit en Pere de Bellviure donarà e constituirà a la dita na Yolant, filla sua, en e per dot de aquella sexanta milia sous, moneda real de València, en los quals sien entesos e compresos aquells quinze milia sous e tot altre qualsevol dret a la dita donzella pertanyent entra lo dit en Pere de Bellviure, pare de aquella, axí per la dot de la dita na Brianda, mare de aquella, com per altra qualsevol causa, manera e rahó.

II. Los quals sexanta milia sous per lo dit en Pere de Bellviure donarà e paguarà al dit micer Gonçalvo hun jorn ans de la celebración de misa en faç de sancta mare sglésia, ço és los quaranta-cinch milia sous en censals esmercats en lochs segurs en lo present regne de València, la propietat dels quals stiga de cara a la dita donzella sien inalienables per seguretat de la dita dot, o en diners comptants si axí al dit en Pere de Bellviure plaurà per obs de smercar en censals que stiguen en la forma dessús dita, e los cinch milia en joyes d'or, pedres, perles, anells, joyells, aquells bé valents a coneguda del dit en Gisbert de Tholosa, e los deu milia sous restants a compliment dels dits sexanta milia sous lo// dit en Pere de Bellviure consignarà e cessionarà e transportarà al dit micer Gonsalvo, ço és, mil florins de Sicília que lo serenísimo senyor rey de Castella e de Sicília pres a cambi del dit en Pere de Bellviure e de Luis Bellviure, germans, los quals dits deu milia sous cobrats que sien e hagen ha esmercar en la forma dessús dita, la qual dita dot se constituheix e constituhia segons fur de València e ab les condicions e vincles infrasegüents, ço és, que si la dita na Yolant moria quant que quant sens fills que en tal cars los dits sexanta milia sous tornen éntegrament sens dampnació alguna al dit en Pere de Bellviure, si viu serà, o als hereus de aquell.

III. Item, és convengut, pactat e concordat que si lo dit micer Gonsalvo en virtut de la cessió a ell fahedora dels dits deu milia sous, debuts del dit cambi, dins cinch anys del dia de la celebració de la missa avant comptadors no havia debuts reyalment aquells dits deu milia sous, en tal cars lo dit en Pere de Bellviure sia tengut paguar aquells en diners o censals en la forma dessús dita, sens interés algú, que del dit temps no s'haga de paguar ne per lo dit en Pere de Bellviure al dit dia per lo dit micer Gonsalvo puixa ésser demanat.

IIII. E per quant, segons fur de València, als vèrgens deu ésser fet creix, és pactat e concordat entre les dites parts que lo dit micer Gonsalvo faça creix o augment a la dita Yolant, donzella, de la mitat de la dot constituïda, que són 
trenta milia sous o més ultra lo dit augment, lo dit micer Gonsalvo li farà axí com ab los presents sa gràcia de cinch milia sous ultra lo dit creix, en axí que en tot cars // e loch de dot e creix restituhidores haga la dita na Yolant dels béns del dit micer Gonsalvo entre dot, augment o creix, gràcia, ço és, dels dits trentacinch milia sous, puixa la dita na Yolant testar e fer ses voluntats entre fills del dit matrimoni e no en altra manera.

$\mathrm{V}$. Item, és convengut, pactat e concordat entre les dites parts que en tot cars e loch que lo dit micer Gonçalvo premorís a la dita na Yolant, aquella haga dels béns del dit son marit una cambra e/o tanta roba, axí de lit ornat, vànoves e lançols e cortinatges que millós se trobaran en la casa del dit micer Gonçalvo en lo temps del seu òbit, e encara de draps de raz e de peus e cófrens, segons és mester per a una cambra honradamente areada, de les quals coses, axí ab fills com sens aquells, puixa fer a ses líberes e planes voluntats ab marit o sens marit. E axí matex mentre que tendrà viduïtat haga statge e habitació la dita na Yolant franch en la casa del dit micer Gonsalvo, de la qual lo dit don Gonsalvo li ha feta donació.

VI. La dita dot, creix e altres coses a la dita na Yolant pertanyents, lo dit micer Gonçalvo asegura sobre tots sos béns haguts e per haver, hon se vol que sien, e senyaladament en e sobre tots aquells béns censals, casa, alqueria, rendes del loch de Calaçeyt e altres coses en dues donacions per lo dit don Gonçalvo, pare del dit micer Gonçalvo, fetes, reeludes per Guillem Exernit, altre dels notaris deiús scrits, a XIII de abril proppassat, en axí que fins que la dita na Yolant en tot cars e loch de dot e creix restituhidor sia paguada éntregament haga la tenuta de tots los dits béns donats e faça los fruyts seus, segons mils li pertanga per fur de València o fur d'Aragó//

VII. Item, és convengut e concordat que lo dit micer Gonçalvo prometrà, sots virtut de jurament per ell prestador e a pena de sis milia florins d'or d'Aragó de pena al dit en Pere de Bellviure aplicadors, que tendrà son domicili, casa e habitació ab sa muller e família en la present ciutat de València e no la mudarà ne permetrà que $\cdot s$ mude de aquella dita ciutat, almenys per temps de sis anys del dia que celebrarà les núbcies en faç de sancta mare sglésia en avant comptadors.

VIII. Item, és convengut, concordat, pactat e convengut entre les dites parts, que vengut a la present ciutat lo dit micer Goncalvo lo dia que·s devia sposar ab la dita na Yolant, loarà, confermarà e aprovarà e de nou fermarà los presents capítols e prometrà les coses dessús dites de la primera línea fins a la darrera inclusive e donarà compliment al dit matrimoni, segons dessús és dit e concordat. 
VIIII. Últimament és convengut, pactat e concordat entre les dites parts que lo dit micer Goncalvo sia tengut venir en la present ciutat de València o allà hon serà la dita donzella fins per tot lo mes de juliol primervinent, sots pena de deu milia florins, e si no vendrà que lo dit en Pere de Bellviure sia delliure de totes les coses promesses per aquell.

E volen les dites parts que los presents capítols sien executoris ab sumissió, renunciació de propri for e altres clàusules necessàries, juraments de no pledegar ne usar de guiatges, de servar los presents capítols e que·n sien fetes dues cartes públiques e que// iuxta forma dels presents capítols sien fermades les cartes nupcials.

Quibusquidem capitulis lectis et publicatis per alienum ex dictis et substutis notariis et per nos intellectis, nos dicte partes dictis nominibus laudantes, aprobantes, facientes, paciscentes atque firmantes omnia et singula in presentis capitulis et eorum singulis pactata, concordata et stipulata per nos, dictis nominibus, et sucesores nostros, quoscumque pacto speciali solempni stipulacione dictis notariis intervenientibus, et cetera; promittimus una partis nunc alteri et altera alteri ad invicem et vicisim ac viceversa atque iuramus ad dictum Deum eiusque sancta quatuor Evangelia manibus nostris dexteris corporaliter tacta, predicta et omnia et singula suppra e infra scripta et in presentis capitulis et eorum singulis singulariter promissa, pactata, concordata et stipulata quantum ad unam quamque partium nostrum predictarum dictis nominibus pertinente et spectant pertinere promittere et spectare videant singula singulis refferendo atendere, tenere et efficaciter complere quem ad modum desuper contentum promisum extitit et concordatum et ullo unquam tempore revocare aut contravenire palam vel occulte aliqua ratione vel causa. Si vero aliqua pars nostrum preinserta capitula et eorum singula et in eis singulariter pactata, concordata, promissa et stipulata in totum vel in partem non observaverit aut ad impleverit que ad modum premissum extitit atque pactatum pacto et stipulacione predictis absque aliqua intimacione, et cetera, ultra penam periurii incidamus et incurramus, incidat et incurrat ultra penam in dictis capitulis apositam, penam duorum mille florenorum auri in auro Aragonum, boni et recti ponderis, de bonis contravenientis vel no ser//vantis et ad implentis exhigendorum et parti parenti et obedienti dandorum et solvendorum ac aplicandorum pro pena et nomine pene, et cetera. Rato pacto, et cetera. Et infrascripta omnia et singula, et cetera; renunciantes scienter omni excepcioni rey sich ut predicitur non geste inhite, convente, promisse et stipulate prout in predictis capitulis et eorum singulis continetur, et doli, mali, excepcioni et condicioni sive causa non data neque secuta et in factum accioni. Et iuri dicenti qui factum promittit interesse per eum soluto omnino liberatur ac alio iuri dicenti generalem renunciacionem, 
et cetera. Cum unicuique sit limitum, pro quibus omnibus et singulis suppra per nos, dictas partes, promissis et inferius promittendis volumus quod possit fieri execucio, et cetera. Fiat extra cum fori submissione, et cetera. Et variaciones iudicii absque expensarum amissione, et cetera. Et renunciacione appellacionis iuste, et cetera. Et recursui et iuri appellandi et recurrendi, et cetera. Et omnibus, et cetera. Et cum clausulam non litigandi cum iuramento nec raciones ponendi nec impetrandi, et cetera. Nec impetrans utendi, et cetera; sub pena predicta, ut prius danda et solvenda, rato semper dicto pacto, et cetera. Et pacto et stipulacione iam dictis promittimus nobis ad invicem et vicisim facere, restituere atque solvere damna, missiones, interesse et expensas, et cetera. De quibus credamur, et cetera, sola asercione medio iuramento, et cetera. Quod nunch pro tunch, et cetera. Quam iuramenti, et cetera. Renunciantes, et cetera. Pro quibus omnibus et singulis tenendis, et cetera. Et ratis habendis obligamus una parte nostrum alteri, et cetera. Videlicet ego, dictus Petrus de Bellviure, omnia bona mobilia, et cetera. Et ego, dictus Gisbertus de Tholosa, omnia bona dicti magnifici principales mei// tam sibi donata per dictum magnificum dominum Gondisalvum Garcia de Sancta Maria, eius patrem, duobus publicis donaciones instructis per dictum Guillermum Exernit, alterum ex notariis subscriptis, in dicta civitate Cesarauguste die XIII a aprilis proxime decurssi, quam cetera alia eius bona mobilia, et cetera. Hec igitur omnia et singula singulis refferendo nobis dicte partes ad invicem et vicisim pacto et stipulacione iamdictis pacisciuntur convenimus, firmamus, promittimus et stipulamur in posse et manu dictorum et subscriptorum notariorum hec a nobis, et cetera. In quorum omnium fidem et attestacionem volumus, et cetera. Actum Valencie.

Testes huius rey sunt: magnifici Alfonsus de Bonilla, miles, de domo spectabilis comitis de Castro et Denie; Gondisalbus Roiz, domicellus et legum doctor; Miquael Aparici, presbiter, habitator, et Tristandus de Leonis, tiraterius, civis Valencie.

Insuper vero die veneris intitulata vicessima secunda dictorum mensis et anni dictorum Gispertus de Tolosa, attendens quod die presenti dictum matrimonium per verba de presentis inter dictum Gispertum, nomine predicto, ex una, et dictam Yolantem, partibus ex altera, compleri debet eam ob rem nomine procuratorio predicto, promissit dicto Petro de Bellviure et dicte Yolanti, absentibus, notariis, et cetera, stipulantibus, et cetera, quod dictus magnificus Gondisalbus Garcia de Sancta Maria in continenti quod erit in presenti civitate Valencie laudabit, aprobabit et de novo firmabit omnia per dictum Gispertum de Tholosa nomine eius facta et firmata in preinsertis// capitulis et instrumentis nubcialibus inde secutis sub penis in dictis capitulis appositis sub obligaciones omnium bonorum dicti principalis sui. Et dictus Petrus de Bellviure, accep- 
tans omnia predicta, absolvit dictum Gondisalvum Garcia a iuramento per dictum Gispertum preterito et pena imposita in penultimo dictorum capitulorum virtute cuius capituli dictus Gondisalvus Garcia erat obligatus venire ad civitatem Valencie predictam per totum mensem iulii primoventurum pro dicto matrimonio implendo, cum dictum matrimonium per verba de presenti, ut predicitur, sit completum. Presentibus pro testibus discreto Johanne Toda, notario, et Johanne Cardona, scriptore.

Post modum vero, die dominica intitulata XVI ${ }^{a}$ mensis ianuarii, anno a nativitate Domini $M^{o} C C C C^{o}$ octuagesimo, in presencia testium subscriptum capitula preinserta per notarios et receptores eorumdem in civitate Valencie fuerunt lecta de verbo ad verbum publicata, dictus magnifico Gondisalvo Garcia de Sancta Maria in predicta civitate personale existens. Et lecta et publicata dicta capitula statim dictus Gondisalvo de Sancta Maria, presente dicto magnifico Petro de Bellviure et acceptante, dixit quod laudabat, aprobabat et ratificabat predicta capitula et omnia et singula in ipsis et quolibet eorum contenta et specificata, a prima eorum linea usque ad ultimam inclusive, tanquam si ab eo personaliter fuissent facta et firmata, cum dictus Gispertus de Tholosa, eius procurator, plenam potestatem habens de eius voluntate et mandato et firmasset. Et ad uberiorem cautelam cum presenti et de presenti ipsa eadem capitula fir/l mabat et firmat. Et promissit dicto Petro de Bellviure, presenti et acceptanti omnia et singula in dictis capitulis contenta, tenere, complere et ad unguem observare et non contravenire sub penis in dictis capitulis contentis per eum modo et forma in ipsis specificatis solvendis. Necnon iuravit ad dictum Deum eiusque sancta quatuor evangelia, manu mea extra corporaliter tacta, omnia et singula in capitulo tenoris sequentis: Item, és convengut e concordat que lo dit micer Gonsalbo prometrà, sots virtut de jurament per ell prestador, a pena de sis milia florins de Aragó de pes al dit en Pere de Bellviure applicadors, que tendrà son domicili, casa e habitació ab sa muller e família en la present ciutat de València e no la mudarà ne permetrà que·s mude de aquella dita ciutat almenys per temps de sis anys del dia que celebrarà les núbcies en faç de sancta mare Sglésia en avant comptadors, a simili tenere, complete et inviolabiliter observare sub dicta pena dicto Petro de Bellviure presenti et acceptanti, danda et solvenda, prout in dicto capitulo continetur, pro quaquidem pena et aliis penis et omnibus in dictis capitulis contentis voluit quod possit fieri exequcio contra eum et eius bona sicut per eius procuratore firmatum et promissum est, cum clausula non litigandi cum iuramento per eum prestito nec raciones ponendi nec impetrandi nec impetratis utendi. Et cum omnibus aliis clausulis in dicto capitulorum instrumento appositus et continuatis, quas pro repentis haberi voluit prout si apposite fuissent et continuate. Pro quibus omnibus et singulis 
tenendis, complendis et observandis, obligavit dicto // Petro de Bellviure, presenti et acceptanti, omnia bona sua mobilia et inmobilia presencia pariter et futura.

Que fuerunt acta, loco et die et anno desuper mencionatis.

Presentibus pro testibus: magnifici Joan Tolsa, miles, et Bernardo Pintor, mercator, civitatis Valencie habitante, et Johannem de la Cavalleria, civis civitatis Cesarauguste. 